\section{Sighting of Tibetan Wolf Canis lupus chanko in the Greater Himalayan range of Nanda Devi Biosphere Reserve, Uttarakhand, India: a new record}

\author{
T. Bhattacharya ${ }^{1} \&$ S. Sathyakumar ${ }^{2}$ \\ 1,2 Wildlife Institute of India, P.O. Box 18, Chandrabani, \\ Dehradun, Uttarakhand 248001, India \\ Email: ${ }^{2}$ ssk@wii.gov.in
}

The Tibetan Wolf is reported to occur in the TransHimalayan regions of India (Fox et al. 1986; Chundawat 1992; Chundawat \& Qureshi 1999). The Indian TransHimalaya is classified under Biogeographic Zone 1 and is represented by Ladakh in Jammu \& Kashmir, Lahul \& Spiti in Himachal Pradesh and northern Sikkim (Rodgers \& Panwar 1988). Very small portions of the Trans-Himalaya are found in Uttarakhand, i.e., in Nanda Devi Biosphere Reserve (BR) and Gangotri National Park (NP). The presence of Tibetan Wolf in Ladakh, Lahaul and Spiti, and northern Sikkim, along with information on livestock depredation has been well documented (Fox et al. 1986; Fox et al. 1991; Chundawat 1992; Chundawat \& Qureshi 1999; Jayapal 2000; Sathyakumar \& Qureshi 2003). In India, two subspecies of wolf are recognized by Sharma et al. (2004): Canis lupus pallipes Indian Grey Wolf and $C$. I. chanko Tibetan Wolf. However, they are considered to be two distinct species by Aggarwal et al. (2007), viz. the Indian Grey Wolf Canis indica and the Himalayan Wolf

Date of publication (online): 26 November 2010

Date of publication (print): 26 November 2010

ISSN 0974-7907 (online) | 0974-7893 (print)

Editor: Michael J.B. Green

\section{Manuscript details:}

Ms \# 02423

Received 11 March 2010

Final received 09 September 2010

Finally accepted 27 October 2010

Citation: Bhattacharya, T. \& S. Sathyakumar (2010). Sighting of Tibetan Wolf Canis lupus chanko in the Greater Himalayan range of Nanda Devi Biosphere Reserve, Uttarakhand, India: a new record. Journal of Threatened Taxa 2(12): 1345-1348.

Copyright: (c) T. Bhattacharya \& S. Sathyakumar 2010. Creative Commons Attribution 3.0 Unported License. JoTT allows unrestricted use of this article in any medium for non-profit purposes, reproduction and distribution by providing adequate credit to the authors and the source of publication.

Acknowledgements: We are thankful to: the Ministry of Environment and Forests, Government of India, for funding support; the Uttarakhand State Forest Department for granting permission; and Director, and Dr. G.S. Rawat at the Wildlife Institute of India for their encouragement and support.

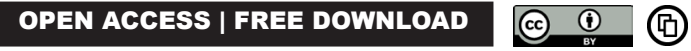

\section{Canis himalayensis.}

The Nanda Devi BR is an important landscape in Uttarakhand that encompasses the Greater and Trans Himalayan regions. Baseline information on the mammalian fauna of Nanda Devi NP and BR are largely from surveys by several naturalists and biologists such as Dang (1961), Khacher (1983), Lamba (1987), Tak \& Kumar (1987), Sathyakumar (1993 $\&$ 2004), and ZSI (1995). None of the aforementioned studies had indicated the presence of Tibetan Wolf in Nanda Devi BR.

With this background, we report sighting Tibetan Wolf at Bedini-Ali $\left(79^{\circ} 40^{\prime} \mathrm{N} \& 30^{\circ} 12^{\prime} \mathrm{E}\right)$ located in the transition zone (Image 1) of Nanda Devi BR while conducting field research on wildlife-habitat interactions at BediniAli during 2005 and 2006 (Bhattacharya et al. 2006, 2009). The Bedini-Ali area, located in the western region of Nanda Devi BR, falls within the Greater Himalayan region and encompasses upper temperate, subalpine and alpine habitats ranging from 3,000 to $5,000 \mathrm{~m}$ and a diversity of slopes and aspects due to the mountainous topography. Vegetation of Bedini-Ali includes: alpine meadows and scrub above the tree limit, dominated by Rhododendron campanulatum, and subalpine forests dominated by Brown Oak Quercus semecarpifolia and Silver Fir Abies pindrow. The average temperature of this area ranges between $18^{\circ} \mathrm{C}$ and $-10^{\circ} \mathrm{C}$; total annual rainfall is over $2,000 \mathrm{~mm}$. Wan is the main village lying west of Bedini-Ali. The subalpine and alpine regions of Bedini-Ali are subjected to high levels of livestock grazing, mainly goats and sheep (c. 5,000) during the summer months (Bhattacharya et al. 2006, 2009).

The first record of Tibetan Wolf was a pair encountered in the vicinity of the deserted tourist hut at Bedini $(3,700 \mathrm{~m})$ during late November 2005 after the first snowfall in the area. These animals were larger than the Red Fox Vulpes vulpes, the only other canid encountered in the study area, and had longer crests of black hair on their back. Subsequently, one or two individuals were recorded on one or more occasions on 16 days between December 2005 and May 2006 in the alpine meadows of Bedini-Ali near the tree line (Image 2). In September 2006, scats of Tibetan Wolf in Nanda Devi BR were recorded from between Malari and Laptal (Trans-Himalaya), located in the eastern part of the BR (Images 1 \& 3). Evidence of wolf was also recorded at Dung (near Milam) and Rimkhim, located in the eastern part of the BR in 2008 (Maheshwari \& Sharma 2010). Local villagers and livestock herders confirmed the presence of wolf (locally called Bheriya) in the Bedini-Ali area and also reported livestock depredation by wolf in the recent past. There were no reports of the presence of feral dogs in this area. Livestock herders reported one instance of livestock killed by wolf in Bedini-Ali during May 2006. 

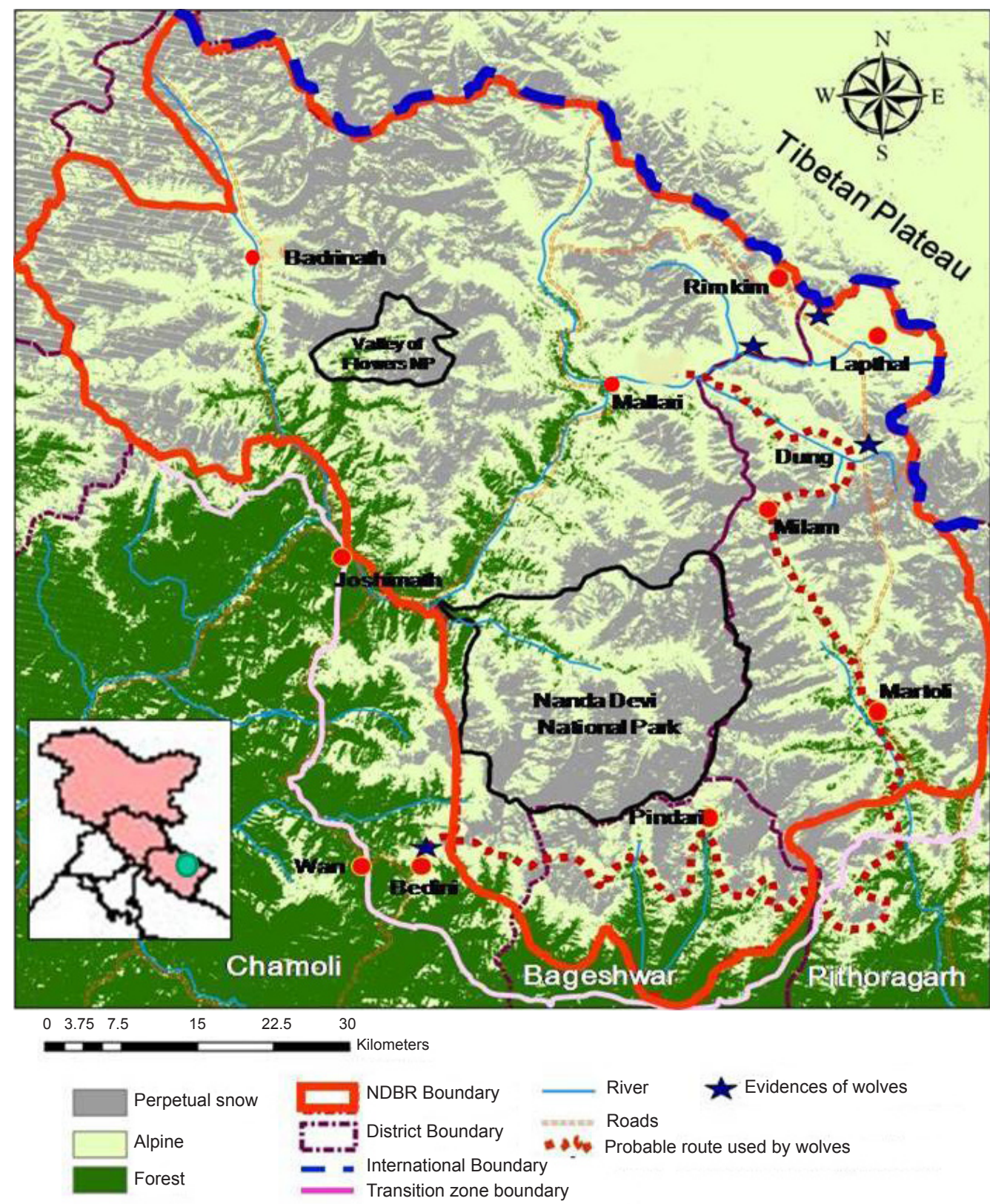

Image 1. A map of Nanda Devi Biosphere Reserve showing the Nanda Devi National Park (core zone), Bedini-Ali where wolf sightings were recorded, and other localities in the buffer zone where wolf evidences were recorded. The probable path that the wolf would have taken to reach Bedini-Ali is also shown.

Two factors need to be addressed while considering this sighting outside its known range. The first factor is obviously the unusual sighting of the Tibetan Wolf (a Trans-Himalayan species) in the alpine regions of BediniAli, which represents moist habitats close to tree line in the Greater Himalaya. The mammalian fauna of Nanda Devi NP and BR has been reasonably well documented through several surveys since the early 1980s (Khacher 1983; Lamba 1987; Tak \& Kumar 1987; ZSI 1995; Sathyakumar 1993, 2004; Kandpal 2010;) and it is very unlikely that a large carnivore such as the Tibetan Wolf would have remained unrecorded. Moreover, with substantial historical and current presence and movements of herders and their livestock in the subalpine and alpine regions of Bedini-Ali, at least secondary reports on the presence of this species should have been reported earlier. However, the absence of records of Tibetan Wolf during earlier scientific surveys, and lack of past reports from local herders and villagers in Bedini-Ali does not necessarily imply that the wolf did not occur in this area in the historical past. The Tibetan Wolf ranges over large areas and a few itinerant individuals may visit peripheral parts of their natural distribution range very occasionally (Y.V. Bhatnagar pers. comm. 2010). Hence, it is likely that 


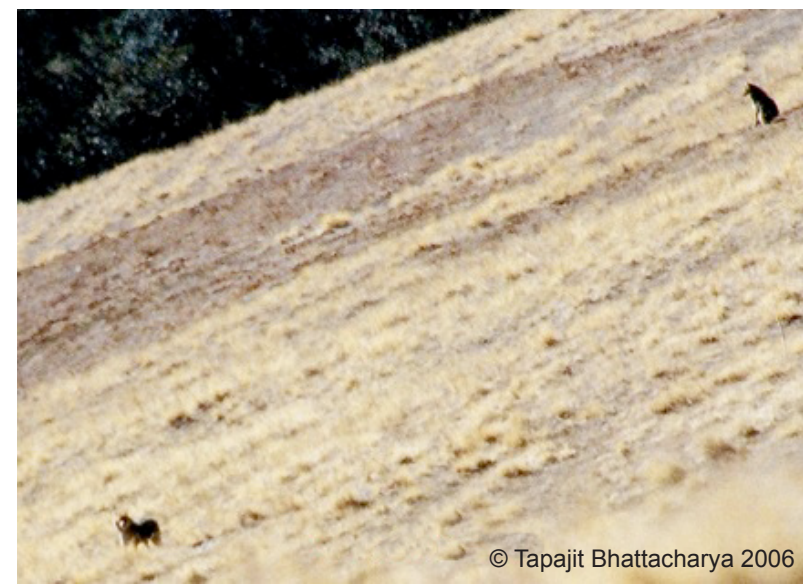

Image 2. A pair of Himalayan Wolves at the 'treeline' in Bedini-Ali, Nanda Devi Biosphere Reserve, November 2005.

the wolf may not have been detected in the past.

Therefore, we hypothesize that the Tibetan Wolf would have probably moved from the Trans-Himalayan parts to the Greater Himalayan parts of Nanda Devi Biosphere Reserve. If this hypothesis is proved to be right, then there is another interesting aspect to these observations. The Trans-Himalayan regions in Nanda Devi are confined to the northern, north-eastern and eastern parts of the BR. There are no reports on the presence of Tibetan Wolf in the vicinity of Bedini-Ali and also from inside the Nanda Devi NP (Lamba 1987; Tak \& Kumar 1987; Sathyakumar $1993,2004)$. The rim of snow capped high peaks (> $6,000 \mathrm{~m}$ ) along the boundary of Nanda Devi NP (Image 1) is presumed to be a barrier for the movement of the Tibetan wolf through the NP and, therefore, it is likely that the Tibetan Wolf inhabiting the Trans-Himalayan regions of Nanda Devi BR (Malari-Laptal) would have moved around the Nanda Devi NP in the buffer zones along the alpine regions towards the west, following migratory livestock herds that graze in these areas during summer (Image 1).

We recommend that field surveys be carried out in Bedini-Ali, Pindari, Milam, Ralam, Malari, Lapthal, Rim Kim and similar habitats in the Nanda Devi BR, using camera traps and use of non-invasive DNA sampling (from scats) to confirm the presence of the Tibetan Wolf in these areas and delineate its distribution in Nanda Devi BR. Simultaneously, thorough surveys should be carried out in villages of transition zone to investigate the extent of local knowledge about presence of wolf and their attitude towards wolf presence. Such investigations will be of great significance in enhancing our understanding of a possible range extension of this species and has implications for conservation and management, as wolfhuman conflicts are a serious issue in other parts of the Indian Trans-Himalaya.

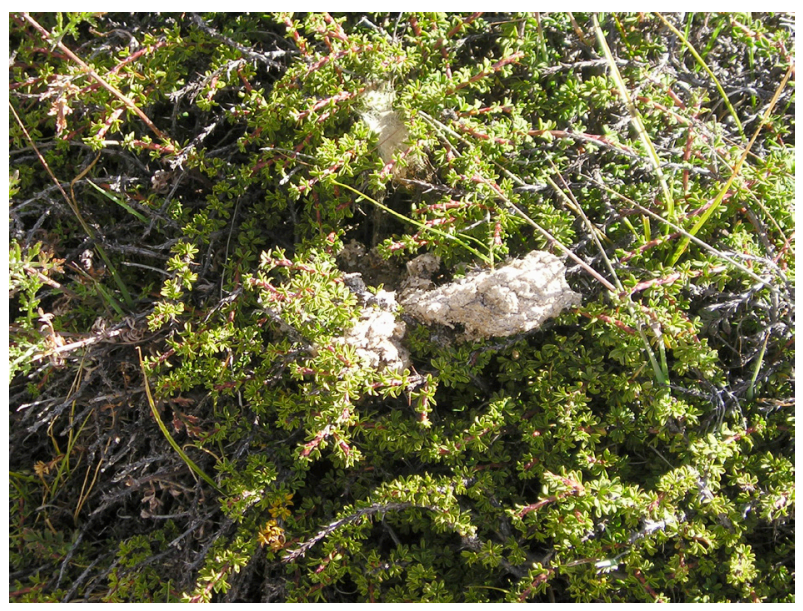

Image 3. Wolf scat on Caragana scrub recorded from MalariLaptal areas in Nanda Devi Biosphere Reserve, September 2006

\section{REFERENCES}

Aggarwal, R.K., T. Kivisild, J. Ramadevi \& L. Singh (2007). Mitochondrial DNA coding region sequences support the phylogenetic distinction of two Indian wolf species. Journal of Zoological Systematics Evolutionary Research 45(2): 163172.

Bhattacharya, T., S. Sathyakumar \& G.S. Rawat (2006). Studies on the Animal - Habitat interactions in the buffer zone of Nanda Devi Biosphere Reserve. Final Report submitted to the Ministry of Environment \& Forests, Govt. of India, New Delhi, 103pp.

Bhattacharya, T., S. Sathyakumar \& G.S. Rawat (2009). Distribution and abundance of Galliformes in response to anthropogenic pressures in the buffer zone of Nanda Devi Biosphere Reserve. International Journal of Galliformes Conservation 1: 78-84.

Chundawat, R.S. (1992). Ecological studies on Snow leopard and its associated species in Hemis National Park, Ladakh. PhD Thesis, University of Rajasthan, 166pp.

Chundawat R.S. \& Q. Qureshi (1999). Planning Wildlife Conservation in Leh and Kargil Districts of Ladakh, Jammu \& Kashmir. Final Report. Wildlife Institute of India, Dehradun, 92pp.

Dang, H. (1961). A natural sanctuary in the Himalayas: Nanda Devi and Rishi Ganga Basin. Journal of Bombay Natural History Socitey 58: 707-714.

Fox, J.L., S.P. Sinha, R.S. Chundawat \& P.K. Das (1986). A survey of Snow Leopard and associated species in the Himalayas of North-Western India. A report. Wildlife Institute of India, Dehra Dun.

Fox, J.L., S.P. Sinha, R.S. Chundawat \& P.K. Das (1991) Status of Snow Leopard Panthera uncia in northwest India. Biological Conservation 55: 283-298

Jayapal, R. (2000). Livestock depredation by wild animals in Zanskar, Ladakh. In: Conserving Biodiversity in the Indian Trans-Himalaya: A New Initiative of Field Conservation in Ladakh. Collaborative Project of Wildlife Institute of India, U.S. Fish \& Wildlife Service \& International Snow Leopard Trust. Wildlife Institute of India, Dehradun

Kacher, L.K. (1983). Nanda Devi - a Goddess desecrated. Sanctuary III(1): 38-49.

Kandpal, V. (2010). Evaluating threatened species in relation to anthropogenic pressures and their management strategy in Nanda Devi Biosphere Reserve, Western Himalaya. PhD 
Thesis. Forest Research Institute University, Dehradun, 256pp.

Lamba, B.S. (1987). Status survey of fauna. Nanda Devi Nationa Park. Occasional paper No. 103. Zoological Survey of India.

Maheshwari, A. \& D. Sharma (2010). Snow Leopard Conservation in Uttarakhand and Himachal Pradesh. WWFIndia, New Delhi, 67pp.

Rodgers W.A. \& H.S. Panwar (1988). Planning a Protected Area network in India - Vol I \& II. Wildlife Institute of India, Dehradun, 336pp \& 267pp

Sathyakumar S. (1993). Status of Mammals in Nanda Devi National Park, pp. 5-15. In: Scientific and Ecological Expedition to Nanda Devi. A report.

Sathyakumar S. (2003). Conservation status of Mammals and Birds in Nanda Devi National Park: An assessment of changes over two decades, pp. 1-14. In: Biodiversity Monitoring Expedition Nanda Devi 2003. A report.

Sathyakumar, S. \& Q. Qureshi (2003). Brown bear - Human Conflicts in Zanskar and Suru Valleys, Ladakh - A Report. Wildlife Institute of India, Dehradun, 21pp.

Sharma, D.K., R.E. Maldonado, Y.V. Jhala \& R.C. Fleischer (2004). Ancient wolf lineages in India. Proceedins of the Royal Society London Biological sciences 271(Suppl.3): S1S4

Tak, P.C. \& G. Kumar, (1987). Wildlife of Nandadevi National Park - An Update. Indian Journal of Forestry 10(13):184190.

ZSI (1995). Fauna of Nanda Devi Biosphere Reserve. Zoological Survey of India, Northern Regional Station, Dehra Dun, $175 p p$. 